\title{
Influence of Calcium Silicate on Soil Fertility and Corn Morphology
}

\author{
Patrick Bezerra Fernandes (Corresponding Author) \\ Federal University of Mato Grosso do Sul, Faculty of Veterinary Medicine and Animal \\ Science, Campo Grande, Mato Grosso do Sul, Brazil. E-mail: zoo.patrick@ hotmail.com
}

Leandro Pires Bitencourt

Federal University of Mato Grosso do Sul, Faculty of Veterinary Medicine and Animal

Science, Campo Grande, Mato Grosso do Sul, Brazil

Gustavo de Faria Theodoro

Federal University of Mato Grosso do Sul, Faculty of Veterinary Medicine and Animal

Science, Campo Grande, Mato Grosso do Sul, Brazil

Uriel de Almeida Curcio

Federal University of Mato Grosso do Sul, Faculty of Veterinary Medicine and Animal

Science, Campo Grande, Mato Grosso do Sul, Brazil

Willian de Assis Theodoro

Federal University of Mato Grosso do Sul, Faculty of Veterinary Medicine and Animal Science, Campo Grande, Mato Grosso do Sul, Brazil

\section{Cássia Oliveira Camargo Barros de Arruda}

Dom Bosco Catholic University, Mato Grosso do Sul, Brazil

Received: Sep. 16, 2019

doi:10.5296/jas.v8i1.15460
Accepted: Oct. 10, 2019 Published: Oct. 20, 2019

URL: https://doi.org/10.5296/jas.v8i1.15460 


\section{Abstract}

The objective of this study was to evaluate whether the development of corn (Zea mays) and soil fertility are influenced by the application of increasing doses of calcium silicate $\left(\mathrm{CaSiO}_{3}\right)$ in substitution to limestone. The experiment was carried out under greenhouse conditions and the experimental design was in randomized blocks, in a $3 \times 2+1$ factorial arrangement and four replications. The factors were: doses of $\mathrm{CaSiO}_{3}\left(7.62 \mathrm{mg} . \mathrm{dm}^{-3}, 19.05 \mathrm{mg} \cdot \mathrm{dm}^{-3}\right.$ and 38.09 $\mathrm{mg} \cdot \mathrm{dm}^{-3}$ ) and liming (absence and presence). The soil of the control treatment did not receive limestone or $\mathrm{CaSiO}_{3}$. At 21 days after emergence (DAE), it was found that the control treatment plants had significantly lower height and stem diameter. At 35 DAE was observed that using exclusively $\mathrm{CaSiO}_{3}$ promoted 6\% higher stem height values. At $63 \mathrm{DAE}$, no oscillations were observed in the biomass of aerial part and root between liming and $\mathrm{CaSiO}_{3}$ doses $(\mathrm{P}>0.05)$. Using the limestone allied the silicate doses increased in higher concentration of $\mathrm{Mg}$ in the soil. The lowest dose of $\mathrm{CaSiO}_{3}$ reduced the concentrations of $\mathrm{Ca}$ and $\mathrm{Mg}$. Calcium silicate can be used as an alternative source to limestone for soil acidity correction.

Keywords: acidity, biomass, $\mathrm{CaSiO}_{3}$, stem

\section{Introduction}

Limestone is a concealer used for centuries to correct soil acidity (Thomason et al., 2019); however, because it presents slow mobility in the soil profile, it can slow its effect in the deeper layers (Ramos et al., 2006) and decelerate the accumulation of biomass aerial part (Lopes et al., 2011; Fabrice et al., 2014).

The use of alternative corrections has been evaluated according to the limitations of limestone. For this reason, the use of silicate-based products were identified as promising corrective, which could positively impact the production of biomass and grains (Crusciol et al., 2013; Ning et al., 2016). In addition, calcium silicate can promote in expressive increases in the contents of exchangeable $\mathrm{Ca}$ and $\mathrm{Mg}$, reducing soil acidity and providing silicon ( $\mathrm{Si}$ ) for plants (Zanao et al., 2017).

Silicon ( $\mathrm{Si}$ ) is a non-essential nutrient for plants, but it stands out in many cultures such as sugarcane (Oliveira et al., 2010), rice (Hyun-Hwoi et al., 2017) and forage grasses (Silveira et al., 2010; Lopes et al., 2011). This element is associated with the reduction of biotic and abiotic stresses of the Si storage plants, such as diseases (Guazina et al., 2019), pest injuries (Antunes et al., 2010; Zargar et al., 2019), salinity (Zhu et al., 2019), drought (Saud et al., 2014) and heavy metal toxicity (Bhat et al., 2019).

Reports on the use of calcium silicate in corn crop are still scarce and generate the need for further studies on the impact that this element may cause in soil chemical attributes and plant morphology in case of limestone substitution.

Thus, the objective of this study was to evaluate whether the development of corn (Zea mays) and how soil fertility are influenced by the application of increasing doses of calcium silicate $\left(\mathrm{CaSiO}_{3}\right)$ in substitution to limestone. 


\section{Material and Methods}

The experiment was conducted at the Faculty of Veterinary Medicine and Animal Science of the Federal University of Mato Grosso do Sul, in the municipality of Campo Grande, MS, under protected cultivation conditions. The regional climate, according to the Köppen classification, is Aw, characterized as tropical, with a well-defined dry season during the cold months and rainy season during the summer. The experimental period comprised from May to June 2018.

\subsection{Soil}

A soil sample was collected in the 0-20 cm layer, classified as a typical Dystrophic Red Latosol, characterized as follows: clayey texture (590 g. kg ${ }^{-1}$ clay, 300 g. $\mathrm{kg}^{-1}$ silt and $110 \mathrm{~g} \cdot \mathrm{kg}^{-1}$ sand); pH: $5.4\left(\mathrm{H}_{2} \mathrm{O}\right)$; organic matter $(\mathrm{OM}): 47 \mathrm{~g} \mathrm{~kg}^{-1}$; base saturation $(\mathrm{V} \%): 44.2 \%$; phosphorus $(\mathrm{P}): 2$ mg dm${ }^{-3}$; potassium $(\mathrm{K}): 0.54 \mathrm{cmolc} \mathrm{dm}^{-3}$; calcium $(\mathrm{Ca}): 4.2 \mathrm{cmolc} \mathrm{dm}^{-3}$, magnesium $(\mathrm{Mg})$ : $2.10 \mathrm{cmolc} \mathrm{dm}^{-3}$; iron $(\mathrm{Fe}): 1.47 \mathrm{mg} \mathrm{dm}^{-3}$; manganese $(\mathrm{Mn}): 111.80 \mathrm{mg} \mathrm{dm}^{-3}$; zinc $(\mathrm{Zn}): 1.75$ $\mathrm{mg} \mathrm{dm}{ }^{-3}$; copper $(\mathrm{Cu}): 3.30 \mathrm{mg} \mathrm{dm}^{-3}$; potential acidity $(\mathrm{Al}+\mathrm{H}): 8.7 \mathrm{cmolc} \mathrm{dm}^{-3}$.

\subsection{Treatments and Experimental Design}

The experimental design was in randomized blocks, in a $3 \times 2$ factorial arrangement with an additional treatment and four replications. The factors were: doses of $\mathrm{CaSiO}_{3}\left(7.62 \mathrm{mg} . \mathrm{dm}^{-3}\right.$, $19.05 \mathrm{mg} . \mathrm{dm}^{-3}$ e $38.09 \mathrm{mg} \cdot \mathrm{dm}^{-3}$ ) and liming (absence and presence). The commercial source of $\mathrm{CaSiO}_{3}$ had $25 \% \mathrm{Ca}, 6 \%$ of $\mathrm{Mg}$ and $10.6 \%$ of Si. Liming was performed with dolomitic limestone ( $80 \%$ PRNT - total relative neutralizing power) to reach the base saturation level of $70 \%$. The soil of the additional treatment (control) did not receive limestone or. Each experimental plot was represented by a vessel containing $8 \mathrm{dm}^{-3}$ of soil. Sowing fertilization was performed, applying $14.83 \mathrm{mg} \cdot \mathrm{dm}^{-3}$ of simple superphosphate and $2 \mathrm{mg} . \mathrm{dm}^{-3}$ potassium chloride, in addition to de $0.8 \mathrm{mg} \cdot \mathrm{dm}^{-3}$ of urea.

After the basic fertilization, the addition of $\mathrm{CaSiO}_{3}$ and limestone in the doses corresponding to the treatments, the soil was homogenized and packaged in pots with $8 \mathrm{dm}^{-3}$ that were kept in a plastic greenhouse. The soil remained incubated for 32 days and was irrigated when necessary for soil moisture to remain at the point of field capacity.

Subsequently, three seeds of corn hybrid SYN 555 were seeding per pot. Ten days after sowing, there was thinning in order to maintain a seedling per pot. In the application of $\mathrm{N}$ in coverage, $1.87 \mathrm{mg} \cdot \mathrm{dm}^{-3}$ of ammonium sulfate was used when the plants reached the phenological stage of V4 (four expanded leaf blades) of the Ritchie et al. (1993) scale.

\subsection{Morphologic Evaluation}

Leaf area estimation was performed at 21 days after emergence (DAE) of plants in the phenological stage V4, by measuring the length (L) and width (W) of all expanded leaves. From this information, the leaf area (LA) was obtained through the expression: $\mathrm{LA}=\mathrm{Lx} \mathrm{W} x$ 0.75 (Tollenaar, 1992). The leaf area per plant was calculated by adding the areas of all expanded leaves. Another six determinations of leaf area were performed at 28, 35, 42, 49, 56 and 63 days after emergence, which corresponded to the phenological stages V5, V7, V8, V9, V10 and V12. 


\section{Macrothink}

Journal of Agricultural Studies

ISSN 2166-0379

2020, Vol. 8, No. 1

In each plant, the diameter and stem height measurements were taken, defined as the distance between the soil and the lygula of the last completely expanded leaf blade.

\subsection{Biomass Estimation of Part Aerial Part and Root}

For the estimation of aerial part biomass, the plants were cut, at the height corresponding to the first knot above the soil surface, to the 63 DAE. The samples were sent to the laboratory, so the plants were fracted in leaf blades and stem. For the estimation of root biomass, they were removed from the vessels, deposited in a sieve with 1 to $2 \mathrm{~mm}$ mesh and washed in gentle running water. Subsequently, the samples of aerial part and root were destined to the greenhouse of forced air circulation at $55^{\circ} \mathrm{C}$ until it reached constant weight.

\subsection{Chemical Characteristics of the Soil}

An aliquot of soil was removed from each vessel and forwarded to the laboratory for the determination of the following chemical attributes, according to Embrapa (1997): $\mathrm{pH}$ in $\mathrm{H}_{2} \mathrm{O}$, $\mathrm{OM}\left(\mathrm{g} \mathrm{kg}^{-1}\right)$, base saturation (V\%), $\mathrm{P}\left(\mathrm{cmolc} \mathrm{dm}^{-3}\right), \mathrm{K}\left(\mathrm{cmolc} \mathrm{dm}^{-3}\right), \mathrm{Ca}\left(\mathrm{cmolc} \mathrm{dm}^{-3}\right), \mathrm{Mg}$ $\left(\mathrm{cmolc} \mathrm{dm}{ }^{-3}\right), \mathrm{Fe}\left(\mathrm{mg} \mathrm{dm}^{-3}\right), \mathrm{Mn}\left(\mathrm{mg} \mathrm{dm}^{-3}\right), \mathrm{Zn}\left(\mathrm{mg} \mathrm{dm}^{-3}\right), \mathrm{Cu}\left(\mathrm{mg} \mathrm{dm}^{-3}\right)$ and potential acidity $\left(\mathrm{Al}+\mathrm{H}\right.$ cmolc $\left.\mathrm{dm}^{-3}\right)$.

\subsection{Statistical Analysis}

Data were subjected to analysis of variance and, when appropriate, Tukey's multiple comparisons test was performed at 5\% significance, using a statistical program $\mathrm{R}$ version 3.5.0. 


\section{Results and Discussion}

\subsection{Morphology}

At 21 DAE, no changes were observed in leaf area values of corn plants subjected to soil correction with $\mathrm{CaSiO}_{3}$ and limestone, in relation to those cultivated under the control treatment (Table 1). Possibly, this fact can be explained by the fact that the plants had not received the effects of the treatments because they were developing the root system (Fancelli, 2017).

Table 1. Leaf area $\left(\mathrm{m}^{2}\right.$ plant $\left.{ }^{-1}\right)$, stem heights $(\mathrm{cm})$ and stem diameter $(\mathrm{cm})$ of corn subjected to $\mathrm{CaSiO}_{3}$ doses as a function of liming

\begin{tabular}{|c|c|c|c|c|}
\hline DAE & Factorial & Control & $P$ value & SEM \\
\hline \multicolumn{5}{|c|}{ 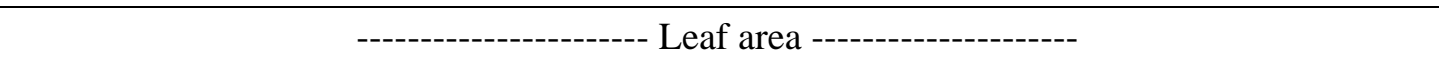 } \\
\hline 21 & $0.612^{\mathrm{a}}$ & $0.492^{\mathrm{a}}$ & 0.999 & 0.043 \\
\hline 28 & $2.35^{\mathrm{a}}$ & $0.940^{\mathrm{b}}$ & 0.003 & 0.142 \\
\hline 35 & $5.40^{\mathrm{a}}$ & $0.450^{\mathrm{b}}$ & 0.008 & 0.574 \\
\hline 42 & $8.94^{\mathrm{a}}$ & $1.09^{\mathrm{b}}$ & $<0.001$ & 0.636 \\
\hline 49 & $13.22^{\mathrm{a}}$ & $1.81^{\mathrm{b}}$ & $<0.001$ & 0.831 \\
\hline 56 & $20.73^{\mathrm{a}}$ & $2.99^{\mathrm{b}}$ & $<0.001$ & 0.974 \\
\hline 63 & $29.28^{\mathrm{a}}$ & $4.39^{\mathrm{b}}$ & $<0.001$ & 1.16 \\
\hline \multicolumn{5}{|c|}{--------------------- Stem height --------------------- } \\
\hline 21 & $11.12^{\mathrm{a}}$ & $8.42^{\mathrm{b}}$ & 0.015 & 0.162 \\
\hline 28 & $18.54^{\mathrm{a}}$ & $9.62^{\mathrm{b}}$ & $<0.001$ & 0.232 \\
\hline 35 & $25.41^{\mathrm{a}}$ & $11.22^{\mathrm{b}}$ & $<0.001$ & 0.380 \\
\hline 42 & $36.95^{\mathrm{a}}$ & $14.37^{\mathrm{b}}$ & $<0.001$ & 0.566 \\
\hline 49 & $49.54^{\mathrm{a}}$ & $19.50^{\mathrm{b}}$ & $<0.001$ & 0.942 \\
\hline 56 & $58.83^{\mathrm{a}}$ & $28.12^{\mathrm{b}}$ & $<0.001$ & 1.08 \\
\hline 63 & $67.45^{\mathrm{a}}$ & $38.75^{\mathrm{b}}$ & $<0.001$ & 1.16 \\
\hline \multicolumn{5}{|c|}{ 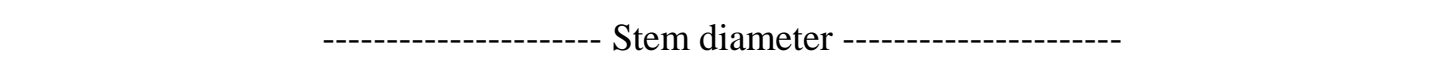 } \\
\hline 21 & $0.645^{\mathrm{a}}$ & $0.437^{\mathrm{b}}$ & 0.003 & 0.019 \\
\hline 28 & $0.979^{\mathrm{a}}$ & $0.462^{\mathrm{b}}$ & $<0.001$ & 0.020 \\
\hline 35 & $1.35^{\mathrm{a}}$ & $0.460^{\mathrm{b}}$ & $<0.001$ & 0.022 \\
\hline 42 & $1.72^{\mathrm{a}}$ & $0.510^{\mathrm{b}}$ & $<0.001$ & 0.022 \\
\hline 49 & $2.03^{\mathrm{a}}$ & $0.620^{\mathrm{b}}$ & $<0.001$ & 0.035 \\
\hline 56 & $2.16^{\mathrm{a}}$ & $0.625^{\mathrm{b}}$ & $<0.001$ & 0.033 \\
\hline 63 & $2.20^{\mathrm{a}}$ & $0.897^{\mathrm{b}}$ & $<0.001$ & 0.031 \\
\hline
\end{tabular}

Averages followed by the same letter in the line do not differ from each other, by the Tukey test at 5\% probability. DAE: days after emergence. $\mathrm{P}$ value: significant effect probability. SEM: standard error of the mean.

In the first evaluation, it was found that the plants that belonged to the control treatment had significantly lower height and stem diameter than those cultivated in corrected soil (Table 1). Therefore, it is possible to infer that there was a high source ratio-drain in the phenological 
stage V4, leading corn plants in the soil acidity correction scenarios, initially investing in the accumulation of stem biomass (Sangoi et al., 2002; Taiz and Zeiger, 2009).

Thus, in the subsequent assessments, because they were in a phenological stage V5 and fully capable of extracting nutrients from the soil, there were changes between treatments that received doses of calcium silicate, with or without liming and control (Table 1). This was due to the fact that the strategies used to increase the $\mathrm{V} \%$ increased the amount of $\mathrm{Ca}, \mathrm{K}$ and $\mathrm{Mg}$ in the soil colloids, allowing the plants to present the maximum nutrient absorption potential, which provided a greater development of plant tissues (Oliveira et al., 2010; Zuba Júnior et al., 2012; Moreira et al., 2014).

For leaf area from 21 to $63 \mathrm{DAE}$, no interaction was observed between the different base saturations and $\mathrm{CaSiO}_{3}$ doses (Table 2). In addition, no differences were observed in the leaf area in both strategies used to reduce soil acidity $(\mathrm{P}>0.05)$, and proportionality was also noticed among the doses of $\mathrm{CaSiO}_{3}(\mathrm{P}>0.05)$. The leaf area is one of the main determinant components of plant growth since on the surface of the leaf blade the photons needed to activate the processes leading to photosynthesis (Taiz and Zeiger, 2009; Gastal and Lemaire, 2015), with the proportionality observed (Table 2), it is possible to infer that the production flow of leaf biomass can present the same behavior.

Table 2. Leaf area $\left(\mathrm{m}^{2}\right.$ plant $\left.{ }^{-1}\right)$ of corn subjected to $\mathrm{CaSiO}_{3}$ doses as a function of liming

\begin{tabular}{|c|c|c|c|c|c|c|c|c|}
\hline \multirow[b]{2}{*}{ DAE } & \multicolumn{2}{|c|}{ Liming } & \multicolumn{3}{|c|}{ Dose of $\mathrm{CaSiO}_{3}\left(\mathrm{mg} \cdot \mathrm{dm}^{-3}\right)$} & \multicolumn{3}{|c|}{ P value } \\
\hline & Absence & Presence & 0.95 & 2.38 & 4.76 & $\mathrm{~L}$ & $\mathrm{D}$ & $\mathrm{L}^{*} \mathrm{D}$ \\
\hline 21 & 0.640 & 0.585 & 0.711 & 0.540 & 0.585 & 0.511 & 0.247 & 0.511 \\
\hline 28 & 2.45 & 2.24 & 2.51 & 2.20 & 2.33 & 0.514 & 0.705 & 0.774 \\
\hline 35 & 5.04 & 5.76 & 6.60 & 4.72 & 4.89 & 0.548 & 0.377 & 0.579 \\
\hline 42 & 8.95 & 8.93 & 10.92 & 7.55 & 8.35 & 0.984 & 0.094 & 0.581 \\
\hline 49 & 13.14 & 13.29 & 15.20 & 12.46 & 11.99 & 0.192 & 0.198 & 0.921 \\
\hline 56 & 20.39 & 21.08 & 22.81 & 20.34 & 19.06 & 0.724 & 0.287 & 0.956 \\
\hline 63 & 29.39 & 29.17 & 31.24 & 27.95 & 28.65 & 0.923 & 0.468 & 0.226 \\
\hline
\end{tabular}

Averages followed by different letters in the line differ from each other, by the Tukey test at 5\% probability. DAE: days after emergence. $\mathrm{P}$ value: significant effect probability. L: liming; D: dose; $\mathrm{L} * \mathrm{D}$ : interaction between liming and dose of $\mathrm{CaSiO}_{3}\left(\mathrm{mg} \cdot \mathrm{dm}^{-3}\right)$.

In the initial stage of plant development (21 DAE; Table 3) the lowest dose of calcium silicate was higher in $12 \%$ in the stem height in relation to liming allied to calcium silicate $(\mathrm{p}<0.05)$. The stem diameter at 28 and 35 DAE presented the same behavior, being observed interaction between doses and liming (Table 3). Thus, it is possible to deduce that calcium silicate provided a higher initial development of the plants. This initial acceleration in the tissue flow allows the plant to reach the reproductive stage early, anticipating the harvesting of the forage (Oliveira et al., 2011). 
Table 3. Stem height $(\mathrm{cm})$ and stem diameter $(\mathrm{cm})$ of corn subjected to $\mathrm{CaSiO}_{3}$ doses as a function of liming

\begin{tabular}{|c|c|c|c|c|}
\hline \multirow[b]{2}{*}{$\begin{array}{c}\text { Doses of } \mathrm{CaSiO}_{3} \\
\left(\mathrm{mg} \cdot \mathrm{dm}^{-3}\right)\end{array}$} & \multicolumn{2}{|c|}{ Liming } & \multirow[b]{2}{*}{ P value } & \multirow[b]{2}{*}{ SEM } \\
\hline & Absence & Presence & & \\
\hline \multicolumn{5}{|c|}{ 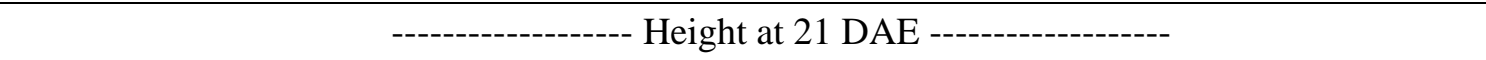 } \\
\hline 0.95 & $12.00^{\mathrm{Aa}}$ & $10.50^{\mathrm{Ab}}$ & 0.015 & 0.411 \\
\hline 2.38 & $11.00^{\mathrm{Aa}}$ & $11.50^{\mathrm{Aa}}$ & 0.661 & 0.226 \\
\hline 4.76 & $10.75^{\text {Аa }}$ & $11.00^{\mathrm{Aa}}$ & 0.384 & 0.163 \\
\hline \multicolumn{5}{|c|}{------------------ Diameter at 28 DAE ----------------- } \\
\hline 0.95 & $1.12^{\mathrm{Aa}}$ & $0.950^{\mathrm{Ab}}$ & 0.016 & 0.046 \\
\hline 2.38 & $0.900^{\mathrm{Ba}}$ & $0.975^{\mathrm{Ab}}$ & 0.270 & 0.032 \\
\hline 4.76 & $0.975^{\mathrm{ABa}}$ & $0.950^{\mathrm{Aa}}$ & 0.709 & 0.018 \\
\hline \multicolumn{5}{|c|}{ 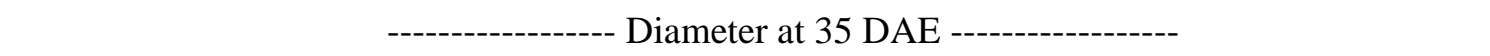 } \\
\hline 0.95 & $1.47^{\mathrm{Aa}}$ & $1.30^{\mathrm{Ab}}$ & 0.014 & 0.044 \\
\hline 2.38 & $1.27^{\mathrm{Ba}}$ & $1.35^{\mathrm{Aa}}$ & 0.260 & 0.039 \\
\hline 4.76 & $1.35^{\mathrm{ABa}}$ & $1.35^{\mathrm{Aa}}$ & 0.999 & 0.032 \\
\hline
\end{tabular}

Averages followed by lowercase equal letters in the rows, and uppercase in the columns do not differ from each other by the Tukey test $5 \%$ probability. DAE: days after emergence. $\mathrm{P}$ value: significant effect probability. SEM: standard error of the mean.

From 28 to $63 \mathrm{DAE}$, no interaction was observed $(\mathrm{P}>0.05)$, at $35 \mathrm{DAE}$ was detected that using only calcium silicate promoted $6 \%$ higher stem height values (Table 4), indicating that the plants showed faster development in this phase. From 42 to 56 DAE, no disproportionality was observed between the sources of variation analyzed (Table 4). Stem-related parings indicate that the experimental scenarios using $\mathrm{CaSiO}_{3}$ and allied liming positively influenced the flow of biomass production of aerial part, since the height and diameter of the stalk are indicators of great importance to predict biomass accumulation (Oliveira et al., 2020). 


\section{MInstitute Macrothink $_{\text {Int }}$}

Table 4. Stem height $(\mathrm{cm})$ and stem diameter $(\mathrm{cm})$ of corn in $\mathrm{CaSiO} 3$ doses as a function of liming during the vegetative phase

\begin{tabular}{|c|c|c|c|c|c|c|c|c|}
\hline \multirow[b]{2}{*}{ DAE } & \multicolumn{2}{|c|}{ Liming } & \multicolumn{3}{|c|}{$\begin{array}{c}\text { Dose of } \mathrm{CaSiO}_{3} \\
\left(\mathrm{mg} \cdot \mathrm{dm}^{-3}\right)\end{array}$} & \multicolumn{3}{|c|}{$P$ value } \\
\hline & Absence & Presence & 0.95 & 2.38 & 4.76 & $\mathrm{~L}$ & $\mathrm{D}$ & $\mathrm{L}^{*} \mathrm{D}$ \\
\hline & \multicolumn{8}{|c|}{ 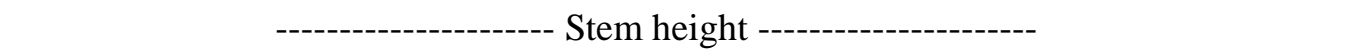 } \\
\hline 28 & 18.83 & 18.25 & 19.00 & 18.50 & 18.12 & 0.195 & 0.280 & 0.195 \\
\hline 35 & $26.16^{\mathrm{a}}$ & $24.66^{\mathrm{b}}$ & 25.00 & 26.25 & 25.00 & 0.045 & 0.264 & 0.156 \\
\hline 42 & 37.33 & 36.58 & 37.12 & 36.75 & 37.00 & 0.494 & 0.958 & 0.430 \\
\hline 49 & 51.00 & 48.08 & 51.87 & 48.50 & 48.25 & 0.083 & 0.145 & 0.782 \\
\hline 56 & 60.41 & 57.25 & 59.87 & 58.12 & 58.50 & 0.116 & 0.739 & 0.483 \\
\hline \multirow[t]{2}{*}{63} & $69.75^{\mathrm{a}}$ & $65.16^{\mathrm{b}}$ & 66.87 & 66.25 & 69.25 & 0.030 & 0.432 & 0.289 \\
\hline & & \multicolumn{7}{|c|}{ 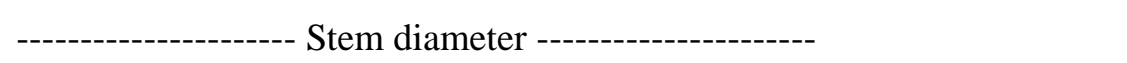 } \\
\hline 21 & 0.633 & 0.658 & 0.675 & 0.637 & 0.625 & 0.566 & 0.619 & 0.467 \\
\hline 42 & 1.70 & 1.73 & 1.73 & 1.68 & 1.73 & 0.466 & 0.392 & 0.999 \\
\hline 49 & 2.00 & 2.06 & 2.05 & 2.03 & 2.02 & 0.361 & 0.947 & 0.433 \\
\hline 56 & 2.18 & 2.14 & 2.17 & 2.17 & 2.13 & 0.494 & 0.840 & 0.873 \\
\hline 63 & 2.25 & 2.17 & 2.21 & 2.26 & 2.16 & 0.139 & 0.267 & 0.705 \\
\hline
\end{tabular}

Averages followed by different letters in the line differ from each other, by the Tukey test at 5\% probability. DAE: days after emergence. $P$ value: significant effect probability. L: liming; $\mathrm{D}$ : dose; $\mathrm{L} * \mathrm{D}$ : interaction between liming and dose of $\mathrm{CaSiO}_{3}\left(\mathrm{mg} \cdot \mathrm{dm}^{-3}\right)$.

The Si when absorbed by the plant polymerizes and accumulates in the cell wall of the epidermis, and may influence the development of the stem diameter increasing its structural resistance (Gomes et al., 2009), possibly this may have occurred from 28 and 35 DAE (Table 3 ), but throughout the development period of corn plants (from the $42 \mathrm{DAE}$ ), probably the correction strategies used reached the maximum acidity correction power, allowing greater nutrient availability, which caused proportionality in tissue flow, indicating that biomass production was not compromised.

\subsection{Corn Biomass and Soil Chemical Composition}

At 63 DAE when the base saturation was corrected using only calcium silicate and/or allied to Liming were superior to the control treatment $(\mathrm{P}<0.05)$, allowing greater increments in the biomass of aerial part (leaf and stem) and biomass of root (Table 5). Probably this may be related to the reduction of soil acidity provided by both the correction strategies, on the other hand, when it did not adopt any strategy of correction of soil acidity, it was observed that the production of biomass per plant was compromised (Table 5). Thus, with the deceleration of plant growth, it reduced the absorption of $\mathrm{K}$, increasing the concentration of this macronutrient in the soil (Table 5). 


\section{Macrothink}

Journal of Agricultural Studies

ISSN 2166-0379 2020, Vol. 8, No. 1

Table 5. Averages related to leaf biomass $\left(\mathrm{g}_{\text {vase }}{ }^{-1}\right)$, stem biomass $\left(\mathrm{g}\right.$ vase $\left.{ }^{-1}\right)$, root biomass ( $\mathrm{g}$ vase $^{-1}$ ) and soil chemical attributes of corn subjected to $\mathrm{CaSiO}_{3}$ doses as a function of liming at 63 days after emergence

\begin{tabular}{|c|c|c|c|c|}
\hline Variável & Factorial & Control & P value & SEM \\
\hline \multicolumn{5}{|c|}{ 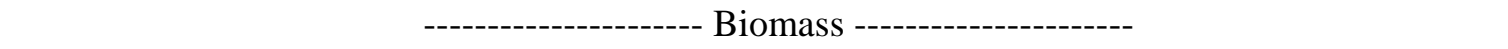 } \\
\hline Leaf & $20.48^{\mathrm{a}}$ & $1.37^{\mathrm{b}}$ & $<0.001$ & 1.39 \\
\hline Stem & $18.21^{\mathrm{a}}$ & $0.550^{\mathrm{b}}$ & $<0.001$ & 1.21 \\
\hline Root & $13.15^{\mathrm{a}}$ & $0.575^{\mathrm{b}}$ & 0.002 & 1.37 \\
\hline \multicolumn{5}{|c|}{ 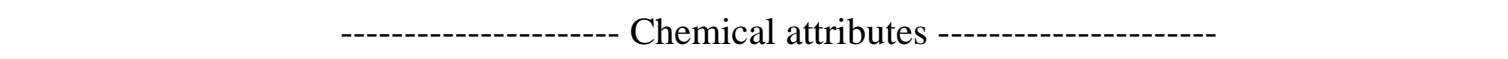 } \\
\hline $\mathrm{pH}$ & $6.37^{\mathrm{a}}$ & $4.82^{\mathrm{b}}$ & $<0.001$ & 0.099 \\
\hline $\mathrm{V}(\%)$ & $80.51^{\mathrm{a}}$ & $55.72^{\mathrm{b}}$ & $<0.001$ & 1.86 \\
\hline MO & $36.84^{\mathrm{a}}$ & $39.37^{\mathrm{a}}$ & 0.415 & 0.869 \\
\hline \multicolumn{5}{|c|}{----------------------- Macronutrients ---------------------- } \\
\hline $\mathrm{P}$ & $59.57^{\mathrm{a}}$ & $2.93^{\mathrm{b}}$ & $<0.001$ & 3.92 \\
\hline $\mathrm{K}$ & $0.292^{\mathrm{b}}$ & $0.620^{\mathrm{a}}$ & $<0.001$ & 0.008 \\
\hline $\mathrm{Ca}$ & $7.77^{\mathrm{a}}$ & $4.32^{\mathrm{b}}$ & $<0.001$ & 0.939 \\
\hline $\mathrm{Mg}$ & $2.75^{\mathrm{a}}$ & $1.65^{\mathrm{a}}$ & 0.999 & 0.122 \\
\hline $\mathrm{H}+\mathrm{Al}$ & $2.60^{\mathrm{b}}$ & $5.25^{\mathrm{a}}$ & 0.002 & 0.229 \\
\hline \multicolumn{5}{|c|}{---------------------- Micronutrients ---------------------- } \\
\hline $\mathrm{Fe}$ & 12.27 & 12.63 & 0.999 & 0.543 \\
\hline $\mathrm{Mn}$ & 10.03 & 8.77 & 0.999 & 0.694 \\
\hline $\mathrm{Cu}$ & 1.71 & 1.48 & 0.999 & 0.346 \\
\hline $\mathrm{Zn}$ & 1.30 & $1.11^{\mathrm{a}}$ & 0.999 & 0.068 \\
\hline
\end{tabular}

Averages followed by different letters in the line differ from each other, by the Tukey test at $5 \%$ probability. Value - P: significant effect probability. SEM: standard error of the mean.

No oscillations were observed in the biomass of aerial part (leaf and stem) and root biomass (Table 6) between liming and calcium silicate doses ( $P>0.05)$. Using the limestone allied to the doses of silicate reduced the potential acidity and increased in higher concentration of $\mathrm{Mg}$ in the soil (Table 6). In addition, higher values of base saturation were observed, being above what was desired (>70\%). Among the doses, it was observed that the lower dose of calcium silicate impacted in lower concentrations of $\mathrm{Ca}$ and $\mathrm{P}$, already at the highest applied dose generated the lowest estimates of potential acidity. In relation to micronutrients, no disproportionality was observed (Tables 5 and 6). 
Table 6. Averages referring to leaf biomass $\left(\mathrm{g} \mathrm{vase}^{-1}\right)$, stem biomass $\left(\mathrm{g}\right.$ vase $\left.{ }^{-1}\right)$, root biomass $\left(\mathrm{g}\right.$ vase ${ }^{-1}$ ) and soil chemical attributes of corn subjected to $\mathrm{CaSiO}_{3}$ doses as a function of liming at 63 days after emergence

\begin{tabular}{|c|c|c|c|c|c|c|c|c|}
\hline \multirow[b]{2}{*}{ Variable } & \multicolumn{2}{|c|}{ Liming } & \multicolumn{3}{|c|}{$\begin{array}{c}\text { Dose of } \mathrm{CaSiO}_{3} \\
\left(\mathrm{mg} \cdot \mathrm{dm}^{-3}\right)\end{array}$} & \multicolumn{3}{|c|}{ P value } \\
\hline & Absence & Presence & 0.95 & 2.38 & 4.76 & $\mathrm{~L}$ & $\mathrm{D}$ & $L * D$ \\
\hline \multicolumn{9}{|c|}{----------------------- Biomass ----------------------- } \\
\hline Leaf & 19.28 & 21.69 & 23.82 & 19.18 & 18.45 & 0.410 & 0.275 & 0.570 \\
\hline Stem & 16.21 & 20.21 & 19.28 & 17.78 & 17.57 & 0.123 & 0.829 & 0.958 \\
\hline Root & 11.64 & 14.65 & 12.27 & 13.20 & 13.97 & 0.213 & 0.839 & 0.136 \\
\hline \multicolumn{9}{|c|}{----------------- Chemical attributes ----------------- } \\
\hline $\mathrm{pH}$ & 6.20 & 6.55 & 6.05 & 6.30 & 6.78 & 0.213 & 0.096 & 0.969 \\
\hline $\mathrm{V}(\%)$ & $76.44 b^{b}$ & $84.59^{\mathrm{a}}$ & $74.15^{\mathrm{b}}$ & $79.38^{\mathrm{ab}}$ & $88.0^{\mathrm{a}}$ & 0.035 & 0.017 & 0.808 \\
\hline MO & 35.99 & 37.69 & 37.45 & 35.71 & 37.36 & 0.357 & 0.679 & 0.964 \\
\hline \multicolumn{9}{|c|}{------------------ Macronutrients ----------------- } \\
\hline $\mathrm{P}$ & 65.15 & 54.00 & $44.28^{\mathrm{b}}$ & $64.70^{\mathrm{ab}}$ & $69.75^{\mathrm{a}}$ & 0.192 & 0.049 & 0.442 \\
\hline $\mathrm{K}$ & 0.285 & 0.300 & $0.276^{\mathrm{b}}$ & $0.278^{\mathrm{b}}$ & $0.323^{\mathrm{a}}$ & 0.343 & 0.048 & 0.726 \\
\hline $\mathrm{Ca}$ & 7.55 & 8.00 & $6.98^{\mathrm{b}}$ & $7.81^{\mathrm{ab}}$ & $8.53^{\mathrm{a}}$ & 0.249 & 0.011 & 0.723 \\
\hline $\mathrm{Mg}$ & $2.32^{\mathrm{b}}$ & $3.19^{\mathrm{a}}$ & 2.52 & 2.82 & 2.92 & 0.004 & 0.451 & 0.699 \\
\hline $\mathrm{H}+\mathrm{Al}$ & $3.06^{\mathrm{a}}$ & $2.13^{\mathrm{b}}$ & $3.33^{\mathrm{a}}$ & $2.81^{\mathrm{ab}}$ & $1.65^{\mathrm{b}}$ & 0.046 & 0.016 & 0.663 \\
\hline \multicolumn{9}{|c|}{------------------ Micronutrients ------------------ } \\
\hline $\mathrm{Fe}$ & 8.13 & 9.41 & 11.90 & 11.15 & 13.77 & 0.108 & 0.116 & 0.720 \\
\hline $\mathrm{Mn}$ & 9.41 & 8.13 & 7.95 & 7.89 & 10.47 & 0.358 & 0.234 & 0.258 \\
\hline $\mathrm{Cu}$ & 1.30 & 2.11 & 1.48 & 1.38 & 2.27 & 0.279 & 0.559 & 0.276 \\
\hline $\mathrm{Zn}$ & 1.32 & 1.28 & 1.41 & 1.32 & 1.17 & 0.792 & 0.301 & 0.102 \\
\hline
\end{tabular}

Averages followed by different letters in the line differ from each other, by the Tukey test at 5\% probability. DAE: days after emergence. $\mathrm{P}$ value: significant effect probability. L: liming; $\mathrm{D}:$ dose; $\mathrm{L} * \mathrm{D}$ : interaction between liming and dose of $\mathrm{CaSiO}_{3}\left(\mathrm{mg} \cdot \mathrm{dm}^{-3}\right)$.

It is noticeable the beneficial effect of $\mathrm{CaSiO}_{3}$ as a possible corrective of soil acidity and calcium supply to the corn crop (Tables 5 and 6), since it positively impacted on soil fertility (Zanao et al., 2017; Liu et al., 2018; Coudert et al., 2019). When the lowest dose of $\mathrm{CaSiO}_{3}$ without limestone was used, the proportional values of biomass were found in relation to the other doses (Table 6), and the recommended dose was to be used in a dystrophic red Latosol. On the other hand, it is still necessary to verify whether this production proportionality will occur when the corn crop reaches the phase of inflorescence and grain filler, considering that, at some moments, the lowest dose used accelerated the development of plants (Tables 3 and 4) and perhaps this event may occur when plants reach the reproductive phase.

\section{Conclusion}

Calcium silicate can be used as an alternative source for elevation of base saturation, improving the chemical composition of the soil, positively impacting the development of aerial part and root system in corn plants. 


\section{Acknowledgements}

To the Coordination of Improvement of Higher Education Personnel - Brazil (CAPES) Financing Code 001, for financial support.

\section{References}

Antunes, C. S., Moraes, J. C., Antônio, A., \& Da Silva, V. F. (2010). Influência da aplicação de silício na ocorrência de lagartas (Lepidoptera) e de seus inimigos naturais chaves em milho (Zea mays L.) e em girassol (Helianthus annuus L.). Bioscience Journal, 26, 619-625.

Bhat, J. A., Shivaraj, S. M., Singh, P., Navadagi, D. B., Tripathi, D. K., Dash, P. K., ... Deshmukh, R. (2019). Role of silicon in mitigation of heavy metal stresses in crop plants. Plants, 8, 71. https://doi.org/10.3390/plants8030071

Coudert, E., Paris, M., Deneele, D., Russo, G.., \& Tarantino, A. (2019). Use of alkali activated high-calcium fly ash binder for kaolin clay soil stabilisation: Physicochemical evolution. Construction and Building Materials, 201, 539-552. https://doi.org/10.1016/j.conbuildmat.2018.12.188

Crusciol, C. A. C., Soratto, R. P., Castro, G. S. A., Da Costa, C. H. M., \& Neto, J. F. (2013). Aplicação foliar de ácido silícico estabilizado na soja, feijão e amendoim. Revista Ciência Agronômica, 44, 404-410. https://doi.org/10.1590/S1806-66902013000200025

Empresa Brasileira de Pesquisa Agropecuária -Embrapa (1997). Manual de métodos de análise de solo. 2.ed, CNPS: Rio de Janeiro. 212p.

Fabrice, S., Eduardo, C., Soares-Filho, C. V., Pinto, M. F., Venturoli Perri, S. H., Cecato, U., \& Mateus, G. P. (2014). Atributos químicos do solo, reservas orgânicas e sistema radicular de pastos degradados associada à introdução de leguminosa. Semina-ciencias Agrarias, 35, 1721-1730. https://doi.org/10.5433/1679-0359.2014v35n4p1721

Fancelli, A. L. (2017). Ecofisiologia, fenologia e implicações básicas de manejo. In: Galvão, J. C. C., Borém, A., Pimentel, M. A. Milho: do plantio à colheita. 2 ed., Viçosa: Ed. UFV, 49-75.

Gastal, F., \& Lemaire, G. (2015). Defoliation, shoot plasticity, sward structure and herbage utilization in pasture: Review of the underlying ecophysiological processes. Agriculture, 5, 1146-1171. https://doi.org/10.3390/agriculture5041146

Gomes, F. B., Moraes, J. C., \& Neri, D. K. P. (2009). Adubação com silício como fator de resistência a insetos-praga e promotor de produtividade em cultura de batata inglesa em sistema orgânico. Ciência e Agrotecnologia, 33, 18-23.

https://doi.org/10.1590/S1413-70542009000100002

Guazina, R. A., Theodoro, G. F., Muchalak, S. M., \& Pessoa, L. G. A. (2019). Aplicação foliar de silício na produtividade e sanidade de cultivares de soja. Revista de Ciências Agroveterinárias, 18, 187-193. https://doi.org/10.5965/223811711812019187

Hyun-Hwoi, K. U., Hayashi, K., Agbisit, R., \& Villegas-Pangga, G. (2017). Nutrient Use of 


\section{MInstitute ${ }_{\text {Mnk }}^{\text {Macrothink }}$}

Lowland Rice and Greenhouse Gas Emission from Paddy Soil in the Philippines Under Alternating Wetting and Drying. Pedosphere.

https://doi.org/10.1016/S1002-0160(17)60401-6

Liu, D. L., Yin, G. C., Chen, Z. L., Lin, Q. T., Liu, Q. J., Zhong, S. X., \& Zhang, J. Q. (2018). Effect of Calcium Silicate-biological Humus Fertilizer Composite on Uptake of Cd by Shallots from Contaminated Agricultural Soil. Huan jing ke xue= Huanjing kexue, 39, 2927-2935. https://doi.org/10,13227/j.hjkx.201709178

Lopes, J., Evangelista, A. R., Fortes, C. A., Pinto, J. C., Furtini-Neto, A. E., \& Souza, R. M. (2011). Nodulação e produção de raízes do Estilosantes Mineirão sob efeito de calagem, silicatagem e doses de fósforo. Ciência Agrotécnica, 35, 99-107.

https://doi.org/10.1590/S1413-70542011000100012

Moreira, S. G., Lupp, R. M., De Lima, C. G., Marucci, R. C., De Resende, Á. V., \& Borges, I. D. (2014). Massa seca e macronutrientes acumulados em plantas de milho cultivadas sob diferentes espécies de cobertura. Revista Brasileira de Milho e Sorgo, 13, 218-231. https://doi.org/10.18512/1980-6477/rbms.v13n2p218-231

Ning, D., Liang, Y., Liu, Z., Xiao, J., \& Duan, A. (2016). Impacts of steel-slag-based silicate fertilizer on soil acidity and silicon availability and metals-immobilization in a paddy soil. PloS one, e0168163. https://doi.org/10.1371/journal.pone.0168163

Oliveira, C. M., Passos, R. R., Andrade, F. V., Reis, E. F., Sturm, G. M., \& Souza, R. B. D. (2010). Corretivos da acidez do solo e níveis de umidade no desenvolvimento da cana-de-açúcar. Revista Brasileira de Ciências Agrárias, 5, 25-31.

https://doi.org/10.5039/agraria.v5i1a541

Oliveira, C. V. V., Barbosa, R. A., Oliveira, R. T., Almeida, E. M., Paludo, F., Lima, J. S., \& Fernandes, P. B. (2020). The tissue flow in Brachiaria brizantha pasture under intermittent stocking. Journal of Agricultural Studies, 8, 9-17.

Oliveira, F. C. L., Jobim, C. C., Da Silva, M. S., Junior, M. C., Junior, V. H. B., \& Roman, J. (2011). Produtividade e valor nutricional da silagem de híbridos de milho em diferentes alturas de colheita. Revista Brasileira de Zootecnia, 40, 720-727.

https://doi.org/10.1590/S1516-35982011000400004

Ramos, L. A., Nolla, A., Korndörfer, G. H., Pereira, H. S., \& Camargo, M. S. (2006). Reatividade de corretivos da acidez e condicionadores de solo em colunas de lixiviação. Revista Brasileira de Ciência do Solo, 30, 849-857.

https://doi.org/10.18512/1980-6477/rbms.v13n2p218-231

Ritchie, S. W., Hanway, J. J., \& Benson, G. O. (1993). How a corn plant develops. Ames: Iowa State University of Science and Technology. (Special Report, 48).

Sangoi, L., Lech, V. A., Rampazzo, C., \& Gracietti, L. C. (2002). Acúmulo de matéria seca em híbridos de milho sob diferentes relações entre fonte e dreno. Pesquisa Agropecuária Brasileira, 37, 259-267. https://doi.org/10.1590/S0100-204X2002000300005 


\section{Macrothink}

Saud, S., Li, X., Chen, Y., Zhang, L., Fahad, S., Hussain, S., Sadiq, A., \& Chen, Y. (2014). Silicon application increases drought tolerance of Kentucky bluegrass by improving plant water relations and morphophysiological functions. The Scientific World Journal, 2014. https://doi.org/10.1155/2014/368694

Silveira, P. M. D., Cunha, P. C. R. D., Stone, L. F., \& Santos, G. G. D. (2010). Atributos químicos de solo cultivado com diferentes culturas de cobertura. Pesquisa Agropecuária Tropical, 40, 283-290. https://doi.org/10.5216/pat.v40i3.5841

Taiz, L., \& Zeiger, E. (2009). Fisiologia vegetal. 4.ed. Tradução SANTARÉM, E.R. et al. Porto Alegre: Artmed, 848p.

Thomason, W. E., Youngman, R. R., Hagood, E. S., \& Alley, M. M. (2019). Successful No-Tillage Corn Production. Produced by Virginia Cooperative Extension, 1, 1-6.

Tollenaar, M. (1992). Is low density a stress in maize? Maydica, 37, 305-311.

Zanao, L. A., Blanco, I. B., Pereira, N., \& Schneider, J. A. (2017). Acidity neutralization and silicon availability using calcium silicate in soil cultivated with wheat ('Triticum aestivum'L.). Australian Journal of Crop Science, 11, 1354. https://doi.org/10.21475/ajcs.17.11.10.pne701

Zargar, S. M., Mahajan, R., Bhat, JA, Nazir, M., \& Deshmukh, R. (2019). Role of silicon in plant stress tolerance: opportunities to achieve a sustainable cropping system. 3 Biotech, 9, 73. https://doi.org/10.1007/s13205-019-1613-z

Zhu, Y. X., Gong, H. J., \& Yin, J. L. (2019). Role of silicon in mediating salt tolerance in plants: a review. Plants, 8,147 . https://doi.org/10.3390/plants8060147

Zuba Júnior, G. R., Sampaio, R. A., Nascimento, A. L., Carneiro, J. P., Santos, L. D. T., \& Fernandes, L. A. (2012). Produção de milho adubado residualmente com composto de lodo de esgoto e fosfato de gafsa.. Revista Brasileira de Engenharia Agrícola e Ambiental, 16, 1289-1297. https://doi.org/10.1590/S1415-43662012001200005

\section{Copyright Disclaimer}

Copyright for this article is retained by the author(s), with first publication rights granted to the journal.

This is an open-access article distributed under the terms and conditions of the Creative Commons Attribution license (http://creativecommons.org/licenses/by/4.0/). 